О.Ю. Шеремета, молодиий науковий співробітник Інституту філософії імені Г.С.Сковороди НАН України

\title{
ЕТИЧНЕ ВЧЕННЯ АНДРЕЯ ШЕПТИЦЬКОГО ПРО ПРИРОДНІ ЧЕСНОТИ
}

Митрополит Андрей Шептицький не лише видатний церковний діяч, а й талановитий мислитель. На основі етики Томи Аквінського йому вдалося створити етичну систему, структуру якої становлять, як у томізмі, етика закону та етика чеснот. Вчення про природні чесноти разом із вченням про надприродні чесноти [1] $€$ важливою складовою останньої. Дослідження його дасть можливість скласти цілісне уявлення про етичну концепцію митрополита. Розгляд етичних ідей Шептицького у релігійно-філософському контексті майже цілком залишився поза увагою дослідників його творчої спадщини. Історіографія, присвячена життю та діяльності митрополита, є досить об'ємною, однак містить лише окремі дослідження, в яких дана проблема розглядається побіжно. Зокрема, це праці В.Ленцика, А.Кравчука, О.Гайової, М.Вавжонека, М.Зимомрі, А.Колодного, Ж.Ковби, Т. Чайки, М. Мариновича, Л.Гентош та ін. Тому історико-філософський аналіз етичного вчення митрополита Андрея в цілому та про природні чесноти, зокрема, залишається актуальним завданням для української історико-філософської науки.

Кожна людина змушена діяти як суб'єкт моральних відносин. В цих діях проявляються чотири основні здатності людської душі: розум, воля, емоційність, чуттєвість. Їм, за вченням Томи Аквінського, повинні відповідати чотири основні природні чесноти. Розум має власною довершеністю головну природну чесноту людини розсудливість. Шептицький підкреслює, що розсудливість може бути мудрістю, якщо вона проявляється як інтуїтивне схоплення істини (теоретична мудрість) чи блага (практична мудрість). Ця теорія виникла в томізмі внаслідок перетлумачення вчення Арістотеля про два види мудрості - теоретичну («софія», власне мудрість) та практичну («фронесіс», розсудливість). Розсудливість $€$ довершеним проявом здатності теоретичного чи практичного судження, в 
якому із правильно встановлених засновків особистість робить правильні висновки. Без неї інші три природні чесноти неможливі. Чеснота розсудливості властива людині як істоті розумній, є проявом іiі головної характерної ознаки - розуму. Сама людська душа називається томістами «розумною душею», а не «духовною», «чуттєвою», «ірраціональною», «таємничою» і т.ін. Розумність душі $\epsilon$ єдиною: вона проявляється однаково в інтуїтивному і дискурсивному мисленні, теоретичній і практичній розумній діяльності. До розсудливості розум схильний сам по собі, бо вона - це природна впорядкованість розуму. Коли людина діє в основному інтуїтивно, то проявляється вища форма розсудливості - мудрість. Навіть ті люди, що не мають розвинутої інтуїтивної розумності, можуть бути розсудливими, використовуючи розум дискурсивно. Тому для кожної людини, при певних зусиллях самопізнання та самоаналізу, стає очевидним, що розсудливість $є$ іiї головною чеснотою. Бути розсудливою так само природно для людини, як бути розумною істотою.

За визначенням Томи, справедливість - це «накладання» (circa) «порядку розуму» (ordo rationis) на дії людини. Вона стає можливим завдяки рішенню та зусиллям волі $[2,667]$. Мужність - це накладання порядку розуму на здатність емоційності, а стриманість на здатність чуттєвості [2, 667]. Концепція чотирьох природних чеснот Томи походить від вчення Платона про чесноти. Згідно із Платоном, розсудливість є чеснотою розуму, мужність - «гніву», стриманість - «бажання», справедливість - всієї людської душі. Тома додає до трьох здатностей душі четверту - волю. Як християнський мислитель, він глибоко розумів роль свободи в житті людини та в історії людства. Виділення волі як інстанції свободи особистості було важливим кроком в розвитку антропології порівняно iз вченням Платона. 3 іншого боку, Тома був згідний із тим, що справедливість належить до порядку дій людини з іншими, із зовнішньою щодо особистості реальністю $[2,667]$. За логікою Платона, це означало, що справедливість повинна бути оцінена як чеснота всієї душі, яка діє назовні як єдине ціле. Тома, однак, розуміє, що душа не проявляється у зовнішній діяльності автоматично. Діяльність душі регулюється волею людини, а тому справедливість $є$ чеснотою волі, а не всієї душі загалом [2, 667]. Якщо вже говорити про те, які чесноти є проявами душі загалом, то, насамперед, слід назвати розсудливість, а вже потім - справедливість [2, 666-667]. 
Ранній неотомізм характеризується поверненням до вчення Томи про природні чесноти. Ці чесноти приписуються людині подвійно: як розумній за сутністю і за діяльністю. Пафос раннього неотомізму був пов'язаний із утвердженням ідеалу метафізичного розуміння Бога, світу, людини. Ці три головні реальності розумілися як сутності, в пізнанні яких убачали останнє слово теології та філософії, віднайдену вічну істину. Тому в ранньому неотомізмі панувала тенденція до опису природних чеснот як довершених проявів людських здатностей - розуму, волі, емоційності, чуттєвості.

Після Першої світової війни під впливом прагматизму і екзистенціалізму розуміння людини як сутності сприймалося дещо анахронічно. Так, у Франції під впливом бергсонізму вважалося хорошим тоном розуміти людську природу як «динамічну». Тому розмови про стабільну «людську» природу не були переконливими навіть для самих неотомістів. Під тиском бергсонізму та екзистенціалізму вони звернули увагу на те, що у самого Томи вчення про чотири чесноти є вченням про чотири довершені стани діяльності людської душі. Перенесення акценту із статичного аспекту вчення Томи про чотири чесноти на динамічний і стало досягненням Ж. Марітена і Е.Жильсона.

Людина в межах екзистенціального томізму Ж.Марітена i Е. Жильсона розглядається як особисте існування (екзистенція), а не як розумна природа (сутність). Чотири моральні чесноти тлумачаться як головні властивості вільної діяльності розумної особистості. Важливим для екзистенціального неотомізму стає вчення про те, що вся людська діяльність спрямована на досягнення безконечного щастя, яке можливе лише в стані блаженного споглядання Бога. При розумінні чеснот як екзистенціалів втрачається метафізична очевидність чеснот як необхідних для людської природи станів. Самостійність етики чеснот при цьому ставиться під сумнів, адже аналіз спрямованості людської діяльності на загальне благо належить до компетенції етики приписів.

Шептицький виходить 3 того, що існують чотири природні чесноти людини: розважливість, мужність, стриманість і справедливість. Розважливість він визначає як правильний спосіб думання в усіх діях та у відношенні до всіх предметів людської волі $[3,305]$. Вона потрібна для віри, бо не дає їй перетворитися на марновірство. Розважливість є тією чеснотою розуму, що дає змогу людині 
знаходити найкращі шляхи для досягнення її власних цілей та особливо вищої мети - блаженного Богоспілкування [3, 304]. Слідом за I Ватиканським Собором (1870р.) Шептицький вважав, що природний людський розум здатний пізнати істину про існування Бога і навіть пізнати властивості Бога. Зокрема, він пише: «Свята наша Мати католицька церква вірить і вчить, що Всевишнього Бога, творця й мету всякого сотворіння, можна напевно пізнати світлом природного розуму з Його діл, себто речей, Ним створених» [3, 161]. Це пізнання є справою розважливості, так само, як і прийняття розумом людини надприродного одкровення.

Мужність і стриманість є чеснотами людської чуттєвості, які притаманні ій настільки, наскільки вона підкоряється розуму взагалі та розважливості як першій чесноті людського розуму. Шептицький пише, що «мужністю треба назвати те загальне розположення душі, яким людина сильно тримається того, що розум велить, проти всяких порушень пристрасті чи трудів праці» [3, 305]. Отже, мужність служить для захисту обраного розумом шляху морального розвитку і прагнення до довершеності. Мужність є силою збереження моральності.

Чеснота стриманості спрямована проти пристрастей та протистоїть аморальності. Християнство не проповідує повного знищення емоційного життя людини: така нечутливість вважалася ідеалом у філософії стоїків. У християнському аскетичному вченні вона є одним із гріховних станів людини - станом духовної смерті. Шептицький вважав, що емоційність має бути не знищеною, а перетвореною - через надання їй розумної міри. Тому дає їй таке визначення: «Здержаністю треба назвати те загальне розположення душі, яке приписує пристрастям і діянням міру» [3, 305].

Четверта чеснота, справедливість, є і властивою для всієї розумної душі і проявом здатності розуму. Це робить іiі схожою на розважливість. Однак остання передує чеснотам мужності та стриманості як їх основа, а справедливість, як чеснота розуму, грунтується і на розважливості, і на мужності, і на стриманості. Адже, щоб бути справедливим, необхідна не лише розважливість (яка, зокрема, включає і знання, що є справедливим), але і мужність, i стриманість. Справедливість «полягає на віддаванні кожному того, що йому належить», що $є$ моральним обов'язком, і тому вона $\epsilon$ «певною правильністю сповнювання своїх обов'язків» [3, 305]. 
Чотири основні чесноти є природними, оскільки мають бути властивими людині, як істоті розумній. Однак вони виникають у особистостей не автоматично чи необхідно, а лише внаслідок систематичних зусиль щодо їх здобуття. Всі чесноти є певними звичками людини вчиняти моральним чином, згідно із нормами, які розумом визнані за природні. Набуття та закріплення звичок $\epsilon$ справою практичною, що здійснюється зусиллями волі. Без пізнання можливості та необхідності вироблення чеснот людина їх мати не може, як у випадку хворих на певні розумові розлади. Але пізнання розумом того, що особистості природно властиві певні чесноти, ще не робить їх наявними у людській душі. Лише здійснення моральних вчинків і становлення позитивних моральних звичок чинити розважливо, мужньо, стримано, справедливо робить людину носієм чотирьох основних чеснот. Тому природні чесноти $\epsilon$ різновидом «набутих чеснот». При цьому «набута чеснота не $\epsilon$ чимось іншим, як вправою чи звичаєм, виробленим через повторювання якихсь добрих вчинків» [3, 309].

Вчення про чесноти як звички є класичним для томізму, однак самим Томою безпосередньо запозичене із творів Іоанна Дамаскіна. А останній спирався на вчення Максима Сповідника про чесноти як навички душі [4]. Тому етика чеснот Шептицького виявляється традиційною як для томізму, так і для духовності християнського Сходу. Але вона різко вирізняється на тлі сучасних етичних вчень етики цінностей та етики обов'язку. Останні органічно увійшли у вчення про чесноти. Така традиція укорінена в етиці античності взагалі та Арістотеля зокрема.

Визнання певних чеснот за природні робить неможливим осудження нехристиян (приречених на зло), що корінилося в теології Августина та було поширене серед протестантів. Останні вважали, що всі чесноти можуть мати лише християни. Митрополит Андрей наголошує на правильності вчення Тридентського Собору, згідно iз яким чесноти погані були дійсними. Таким чином, Шептицький визнає можливість і необхідність загальнолюдської моралі. Але вона не тотожна радикальній тезі II Ватиканського Собору про те, що всі доброчесні нехристияни є «анонімними католиками» і можуть спастися. Митрополит слідує за Томою, заявляючи, що для спасіння наявності цих справжніх чеснот ще недостатньо; для цього потрібне благодатне рішення Бога про дарування Царства Божого 
нехристиянам, які мають означені чесноти. Та позитивна оцінка справжності моральних чеснот у нехристиян свідчить, що Шептицький був на шляху до вчення II Ватиканського собору про анонімне християнство всіх доброчесних нехристиян. Він пише: «Треба також признати, що Бог може давати Свою благодать такими дорогами й способами, про які нам не сниться. Треба сказати, що коли невіруючий чоловік робить те, що може, Бог йому не відмовить Своєї благодаті» $[3,309]$. Віра (як вірність Богові) обов'язково необхідна лише для набуття благодаті освячення. Тобто невіруючий праведник, на думку митрополита, може ввійти в Царство Боже, але не може бути святим. Таке вчення дає можливість виправдати відкритість до праведності нехристиян та зберегти уявлення про специфічну цінність християнської праведності. Нехристиянамиправедниками можуть бути як представники інших релігій, так і зовсім невіруючі. Визнання цінності чеснот всіх людей $є$ основою для діалогу не лише екуменічного, а й з представниками секуляризованого світогляду.

Розуміння чеснот як звичок (навичок) породжує вчення Шептицького про можливості розвитку та деградації чеснот. Згідно 3 ним, чесноти можуть розвиватися лише тоді, коли особистість докладає більше зусиль в здійсненні чесноти, ніж зазвичай. А при збереженні одного рівня зусиль вони «маліють» $[3,331]$. Такі уявлення породжені християнською аскетичною традицією католицької церкви. Тому Шептицький вважає, що лише при постійному збільшенні зусиль для набуття чеснот може зростати моральність людської душі. Його уявлення є органічними для аскетики католицької церкви, що передбачає постійне героїчне наростання жертовності людини та трансценденцію особистості над собою. Але і західна, i східна традиції аскетизму погоджуються, що при зменшенні напруження для здійснення чеснот природні чесноти маліють «через те, що ростуть противні їм хиби й пороки» [3, 331]. Отже, згідно із Шептицьким, моральне життя всіх людей, що мають природні чесноти, $є$ постійним героїзмом, а не механічним здійснення обов'язку.

Етика природних чеснот у митрополита є етикою творчого процесу самотворення людини. Для цього їй необхідно, докладаючи постійних особистих зусиль, набути чотири природні чесноти. Самотворення моральної особистості є природним покликанням кожної людини, а отже, - родовим покликанням людства. Його здійснення 
кожним має на меті кінцевий стан блаженства всіх - Царство Боже. Але ця далека і на землі недосяжна мета передбачає дві ближчі: моральність самої особи (самотворення кожного) та моральність всього людства. Людина відповідальна лише за власну моральність. Тому ідеал моральності всього людства здійснюється зусиллями окремих особистостей, які ставлять собі за мету служіння загальному благу. Його особистість вже тому повинна мати власну мету, що цього вимагає одна із природних чеснот - справедливість. Розважливість, як пізнання істини, підтверджує розумну обгрунтованість цієї вимоги справедливості. Мужність готова обстоювати те, що розважливість і справедливість визначили як загальне благо. Відповідно, стриманість є природною схильністю до відмови від усього, що суперечить загальному благу.

В XX ст. виникає «нова онтологія» Г.Гайдеггера, Н.Гартмана, яка виходить за межі альтернатив між ідеалізмом і матеріалізмом,

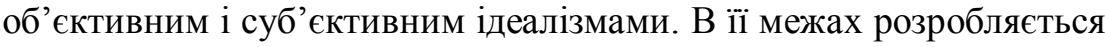
нове розуміння чеснот як цінностей. Вони не мають ні об'єктивного, ні суб'єктивного статусу, але проявляються в людському житті особистому та культурно-історичному. Для Н. Гартмана, природні цінності $є$ центральним елементом «першої групи цінностей», до якої в середньовіччі додаються «цінності другої групи» (серед яких головні - любов, надія, віра). Поява природних цінностей є закономірним процесом для античної культури, а «християнських цінностей» - для середньовічної. Н. Гартман відмовляється обмежувати цінності «першої групи» класичними чотирма чеснотами і додає до них численні чесноти, виявлені Арістотелем. Оскільки для нього відмінність між суттєвим і несуттєвим є метафізичним забобоном, який він розкритикував в «Основних принципах онтології», то в «Етиці» [5] він описує всі чесноти античної людини. Своїм завданням Гартман вважав повноту феноменологічного опису, за якого всі чесноти розуміються як цінності. Антична теорія про те, що чотири чесноти $є$ довершеностями різних здатностей душі, зовсім його не цікавить. Проте саме розгляд чеснот (античними і середньовічними етиками, Шептицьким та іншими неотомістами) як довершених проявів різних здатностей душі надавав їм об'єктивного статусу (в очах цих теоретиків). Інакше вони $є$ саме цінностями, онтологічний статус яких оцінюється кожним філософом довільно. Також і до трьох християнських чеснот віри, надії та любові Гартман 
приєднує інші численні християнські чесноти, про які відомо із аскетичної літератури. Він визнає, що середньовічні теоретики відносили християнські чесноти до досконалих виявів особистості і цим протиставляли їх природним чеснотам (які були виявами людської сутності). Але навіть при такому визнанні Гартман не аналізує віру, надію та любов як три визначальні для особистості екзистенціали. Він аналізує ці чесноти нарівні $з$ іншими, намагаючись довести, що вони мають відносне, культурно-історичне значення. За Гартманом, в Новий час до античних та середньовічних цінностей додано нові (свободи, самотворення, персоналістичності тощо), а старі принципово переосмислено. Цей процес Гартман оцінює позитивно. І якщо М.Шелер пропонує від суспільства споживацтва і урівнювання повернутися до аскетичних цінностей давнини, оскільки людству загрожують різні кризи, то Гартман лише вважає бажаною роботу з відтворення наявних у людства цінностей. Учень Н.Гартмана Д. Гільдебранд намагався повернути аналіз цінностей в русло звичайної онтології, приписуючи цінності ідеальному суб'єкту, але визнаючи культурно-історичний характер їх прояву [6, 102-106]. Ця теорія Гільдебранда вплинула на етику сучасного неотомізму, але не могла вплинути на етику Шептицького. Теорії чеснот як цінностей були невідомі митрополиту, а філософська позиція їх авторів - неприйнятною. Він був теїстичним та метафізичним об'єктивним ідеалістом. Його релігійно-філософська позиція мала консервативний характер, який був характерним для всього раннього неотомізму, відмова від якого, і то не повністю, спостерігається у екзистенціалістських та трансцендентальних неотомістів.

Отже, Андрей Шептицький цілком і повністю перебуває в межах етики чеснот раннього неотомізму. В його творах творчо і різнобічно розкривається іiі потенціал як вчення про довершеності розумної природи людини. Митрополит знає вчення Томи про чесноти як властивості діяльності особистості, але дає цьому вченню не екзистенціальну, як у Ж. Марітена і Е.Жильсона інтерпретацію, а метафізичну. Згідно із Шептицьким, чесноти можуть розглядатися як властивості людської діяльності тільки тому, що вони, насамперед, $\epsilon$ властивостями людської природи, довершеними станами людських здатностей. Людина $є$ розумною і вільною істотою за своєю сутністю, а ії діяльність - проявом людської розумності та свободи. Чесноти як властивості людської діяльності є проявами природної 
схильності людини до добра. Шептицький вибудовує власну етику чеснот як цілісну систему, в якій чесноти послідовно аналізуються як прояви: природних здатностей людської душі, природних схильностей цих здатностей, природних дій особистості як реалізації схильностей. Така побудова етики чеснот найбільш близька до етики чеснот св. Томи Аквінського. Таким чином, Шептицький не перейшов від ранньонеотомістського до екзистенціального типу етики чеснот томізму.

Шептицький створив цілісне вчення про чотири чесноти: розсудливість як чесноту розуму, мужність як чесноту емоційності, стриманість як чесноту чуттєвості та справедливість як чесноту волі. Вони є природними, оскільки мають бути властивими людині як істоті розумній. Але чесноти виникають у особистостей не автоматично чи за необхідністю, а із набуттям людиною певних звичок вільно вчиняти моральним чином, згідно із нормами, які розумом визнані за природні. Етика природних чеснот у Шептицького $\epsilon$ творчим процесом самотворення особистості, яскравим свідченням гуманізму митрополита. Розвиток вчення про чесноти як довершеності природних властивостей душі відрізняється власним консерватизмом від сучасного феноменологічного розуміння цих чеснот як цінностей (М.Шелер, Н.Гартман, Д.Гільдебранд). Шептицький максимально повно використав вчення Томи Аквінського про природні чесноти для обгрунтування загальноідеалістичного i християнського гуманізму.

\section{ЛІТЕРАТУРА}

1. Шеремета О.Ю. Етичне вчення Андрея Шептицького про надприродні чесноти // Мультиверсум. Філософський альманах. - К., 2010. Вип. 4(92). - С. 127-139.

2. Фома Аквинский. Сумма теологии. - Ч. ІІ-1: Вопросы 1-67. - М., 2008. $-750 \mathrm{c}$.

3. Шептицький Андрей. Християнська праведність // Митрополит Андрей Шептицький. Твори (аскетично-моральні). - Львів, 1994. - С. 127-408.

4. Чорноморець Ю., Левченко T. Віра як акт розуму (згідно із вченням Максима Сповідника і Томи Аквінського) // Колегія. Часопис Інституту релігійних наук св. Томи Аквінського в Києві. - 2008. - № 3 (16). C. $137-153$. 
5. Гартман Н. Этика. - СПб., 2002. - 708 с.

6. Гільдебранд Дитріх фон. Етика. - Львів, 2002. - 445 с.

Шеремета О.Ю. Етичне вчення Андрея Шептицького про природні чесноти.

У статті висвітлюється етичне вчення митрополита Андрея Шептицького про природні чесноти, яке є важливою складовою його етичної системи. Природні чесноти митрополит розуміє як довершений вираз людської природи. Їх він нараховує чотири: розсудливість як чеснота розуму, мужність як чеснота емоційності, стриманість як чеснота чуттєвості та справедливість як чеснота волі. Вони $є$ природними, оскільки мають бути властивими людині як істоті розумній. Але чесноти виникають у особистостей не автоматично чи за необхідністю, а з набуттям ними певних звичок вільно вчиняти моральним чином, згідно із нормами, які розумом визнані за природні. Етика природних чеснот у Шептицького є творчим процесом самотворення особистості. Вона побудована на основі етичного вчення Томи Аквінського та цілком перебуває у межах раннього неотомізму. Шептицький дає ӥй не екзистенціальну, як у Ж.Марітена і Е.Жильсона інтерпретацію, а метафізичну. Таким чином, митрополит не переходить від ранньонеотомістського до екзистенціального типу етики чеснот томізму. Його вчення про чесноти як довершеності природних властивостей душі суттєво відрізняється від сучасного феноменологічного розуміння цих чеснот як цінностей (М.Шелер, Н.Гартман, Д.Гільдебранд). Андрей Шептицький максимально повно використав вчення Томи Аквінського про природні чесноти для обгрунтування загальноідеалістичного і християнського гуманізму.

Ключові слова: Андрей Шептицький, етика, природні чесноти, неотомізм

Шеремета О.Ю. Этическое учение Андрея Шептиикого о естественных добродетелях.

В статье освещается этическое учение митрополита Андрея Шептицкого о естественных добродетелях, которое является важной составляющей его этической системы. Естественные добродетели митрополит понимает как совершенное выражение человеческой природы. Их он насчитывает четыре: рассудительность как добродетель ума, мужество как добродетель эмоциональности, сдержанность как добродетель чувственности и справедливость как добродетель воли. Они являются естественными, поскольку должны быть присущи человеку как существу разумному. Но добродетели появляются у личностей не автоматически или по необходимости, а с приобретением человеком определенных привычек: свободно

ISSN2078-8142 Мультиверсум. Філософський альманах.-2015.-Випуск 3-4(141-142) 99 
поступать моральным образом, согласно нормам, которые умом признаются естественными. Этика естественных добродетелей у Шептицкого является творческим процессом самосозидания личности. Она построена на основе этического учения Фомы Аквинского и целиком находится в рамках раннего неотомизма. Шептицкий даёт ей не экзистенциальную интерпретацию, как у Ж. Маритена и Э.Жильсона, а метафизическую. Таким образом, митрополит не переходит от ранненеотомистского к экзистенциальному типу этики томизма. Его учение о добродетелях как совершенстве естественных свойств души у него существенно отличается от современного феноменологического понимания этих добродетелей как ценностей (М.Шелер, Н.Гартман, Д.Гильдебранд). Шептицкий максимально полно использовал учение Фомы Аквинского о естественных добродетелях для обоснования общеидеалистического и христианского гуманизма.

Ключевые слова: Шептицкий, этика, естественные добродетели, неотомизм.

Sheremeta O. Ethical teaching Andrey Sheptytsky about the natural virtues.

The article highlights the ethical teachings of Metropolitan Andrey Sheptytsky on natural virtues which are an important part of his ethical system. Under natural virtues Metropolitan understands the perfections of human nature. These are the following: prudence as the virtue of mind, courage as the virtue of emotion, restraint as the virtue of sensuality, and justice as the virtue of will. These virtues are natural because they should be characteristic to the man of sense. But the virtues do not occur in individuals automatically or out of necessity. They emerge along with the acquisition of certain habits to freely behave in a moral way in accordance with the rules which the mind recognizes as natural.

By Sheptytsky, the ethics of the natural virtues is a creative process of self-identity. It is based on the ethical teachings of Thomas Aquinas and is entirely within the boundaries of the early neo-Thomism. Unlike Jacques Maritain and E. Gilson, Sheptytskygives the ethics not an existential but a metaphysical interpretation. Thus, Metropolitan does not switch from early neoThomistic to existential type of the ethics of Thomism. The teachings on the virtues as the perfections of natural properties of the soul are essentially different from the modern phenomenological understanding of these virtues as values (Scheler, Hartmann, Hildebrand). Sheptytsky has fully used the teachings of St. Thomas Aquinas on the natural virtues to justify generally idealistic Christian humanism.

Key words: Sheptytsky, ethics, natural virtues, neo-Thomism. 